\title{
Mechanism and Time Course of Cocaine-Induced Long- Term Potentiation in the Ventral Tegmental Area
}

\author{
Emanuela Argilli, ${ }^{1,2}$ David R. Sibley, ${ }^{3}$ Robert C. Malenka, ${ }^{4}$ Pamela M. England, ${ }^{5,6}$ and Antonello Bonci ${ }^{1,2}$ \\ ${ }^{1}$ Ernest Gallo Clinic and Research Center and ${ }^{2}$ Department of Neurology, University of California, San Francisco, Emeryville, California $94608,{ }^{3}$ Molecular \\ Neuropharmacology Section, National Institute on Neurological Disorders and Stroke, National Institutes of Health, Bethesda, Maryland 20892, ${ }^{4}$ Nancy \\ Pritzker Laboratory, Department of Psychiatry and Behavioral Sciences, Stanford University School of Medicine, Palo Alto, California 94304, and \\ Departments of ${ }^{5}$ Pharmaceutical Chemistry and ${ }^{6}$ Cellular and Molecular Pharmacology, University of California, San Francisco, San Francisco, California \\ 94158
}

Synaptic plasticity in the ventral tegmental area (VTA) has been implicated in the acquisition of a drug-dependent state. Even a single exposure to cocaine in naive animals is sufficient to trigger sustained changes on VTA glutamatergic synapses that resemble activitydependent long-term potentiation (LTP) in other brain regions. However, an insight into its time course and mechanisms of action is limited. Here, we show that cocaine acts locally within the VTA to induce an LTP-like enhancement of AMPA receptor-mediated transmission that is not detectable minutes after drug exposure but is fully expressed within $3 \mathrm{~h}$. This cocaine-induced LTP appears to be mediated via dopamine $\mathrm{D}_{5}$ receptor activation of NMDA receptors and to require protein synthesis. Increased levels of high-conductance GluR1-containing AMPA receptors at synapses are evident at $3 \mathrm{~h}$ after cocaine exposure. Furthermore, our data suggest that cocaineinduced LTP might share the same molecular substrates for expression with activity-dependent LTP induced in the VTA by a spiketiming-dependent (STD) protocol, because we observed that STD LTP is significantly reduced or not inducible in VTA neurons previously exposed to cocaine in vivo or in vitro.

Key words: cocaine; dopamine; glutamate receptor; long-term potentiation (LTP); patch clamp; ventral tegmental area

\section{Introduction}

Activity-dependent modifications of synapses are a key mechanism underlying many functions of the brain. The most studied models of persistent plasticity are long-term potentiation (LTP) and long-term depression (LTD) of glutamatergic synapses, phenomena that are commonly thought of as cellular substrates for learning, memory, and developmental plasticity (Malenka and Bear, 2004; Kim and Linden, 2007). Exposure to cocaine and other drugs of abuse seems to induce similar long-term changes of synaptic efficiency among neurons in the motivational/reward system [for review, see Jones and Bonci (2005) and Kauer and Malenka (2007)]. A key study providing direct evidence for drugdependent plasticity at excitatory synapses in the mesolimbic dopamine (DA) system showed that a single injection of cocaine in rodents induces a potentiation of AMPA receptor (AMPAR)mediated excitatory synaptic transmission onto DA-releasing neurons in the ventral tegmental area (VTA) $24 \mathrm{~h}$ later (Ungless et al., 2001).

The VTA is a central component of the mesocorticolimbic

\footnotetext{
Received March 6, 2008; revised July 29, 2008; accepted Aug. 1, 2008

This work was supported by National Institute on Drug Abuse Grant 1R01DA15096 (A.B.) and by funding from the state of California for medical research on alcohol and substance abuse through the University of California, San Francisco (A.B.). We thank the members of the Bonci and Malenka laboratories for helpful discussions and Lisa $G$. Daitch for proofreading.

Correspondence should be addressed to Dr. Antonello Bonci, Ernest Gallo Clinic and Research Center, 5858 Horton Street, Suite 200, Emeryville, CA 94608. E-mail: antonello.bonci@ucsf.edu. D0I:10.1523/JNEUROSCI.1001-08.2008

Copyright $\odot 2008$ Society for Neuroscience $\quad 0270-6474 / 08 / 289092-09 \$ 15.00 / 0$
}

network. A sustained modification in the strength of glutamatergic synapses onto dopaminergic VTA neurons would be expected to cause a change in their activity and DA release to target regions, thus ultimately influencing and perhaps remodeling the reward neuronal circuitry. Indeed, cocaine-induced synaptic plasticity in the VTA has been associated with maladaptive behaviors and the development of addiction (Jones and Bonci, 2005; Nestler, 2005; Kauer and Malenka, 2007). Thus, a detailed understanding of the molecular mechanisms underlying the induction and expression of cocaine-induced LTP in VTA DA neurons will provide important clues to the circuit modifications that eventually lead to addiction.

Previous studies have demonstrated that enhancement of glutamatergic synaptic transmission induced by acute cocaine is NMDA receptor (NMDAR) dependent, is transiently expressed for at least 5 but less than $10 \mathrm{~d}$, and positively correlates with the initial phase of behavioral sensitization but not with its expression (Ungless et al., 2001; Borgland et al., 2004). Moreover, recent evidence suggests that synaptic insertion of high-conducting GluR1-containing receptors might contribute to expression of this cocaine-induced synaptic plasticity (Bellone and Lüscher, 2006). A similar process involving the trafficking of specific subunit-containing AMPA receptors to synapses also underlies LTP in other brain regions (Song and Huganir, 2002; Bredt and Nicoll, 2003; Malenka and Bear, 2004). Indeed, recombinant GluR1s expressed in hippocampal CA1 pyramidal cells rapidly redistribute to the synaptic membrane within minutes after LTP- 
inducing stimulation in an NMDAR-dependent manner (Shi et al., 1999). However, whether cocaine-induced LTP in VTA DA neurons follows a similar time course is unknown, as are its underlying mechanisms.

We previously showed that acute cocaine perfusion onto midbrain rat slices fails to increase AMPAR-mediated transmission of VTA DA cells, whereas NMDAR-mediated transmission is rapidly enhanced via $D_{1}$-like DA receptor activation of protein kinase A (PKA) activity (Schilström et al., 2006). Whether this modulation of NMDARs is necessary for LTP-like strengthening of AMPAR transmission observed $24 \mathrm{~h}$ after cocaine administration is unknown. Here we further investigate the time course and mechanisms of cocaine-induced LTP in VTA DA neurons and also whether it influences the spike-timing-dependent LTP that occurs in these cells.

\section{Materials and Methods}

Three- to four-week-old Sprague Dawley rats were anesthetized and killed. The brain was rapidly dissected, and horizontal slices $(230 \mu \mathrm{m}$ thick) containing the VTA were prepared using a Vibratome. Slices were allowed to recover for at least $45 \mathrm{~min}$ in artificial CSF [aCSF; containing the following (in mM): $126 \mathrm{NaCl}, 1.6 \mathrm{KCl}, 2.4 \mathrm{CaCl}_{2}, 1.2 \mathrm{NaH}_{2} \mathrm{PO}_{4}, 1.2$ $\mathrm{MgCl}_{2}, 18 \mathrm{NaHCO}_{3}$, and 11 glucose, saturated with $95 \% \mathrm{O}_{2}$ and $5 \%$ $\mathrm{CO}_{2}$ ] before being transferred individually to the recording chamber and superfused with continuous flow $(2 \mathrm{ml} / \mathrm{min})$ of aCSF at $32^{\circ} \mathrm{C}$ containing picrotoxin $(100 \mu \mathrm{M})$ to block $\mathrm{GABA}_{\mathrm{A}}$ receptor-mediated synaptic currents.

Cells were visualized using an upright microscope with infrared illumination. Whole-cell voltage-clamp recordings were made using an Axopatch 1D amplifier (Molecular Devices) with 3-5 $\mathrm{M} \Omega$ glass electrodes containing the following (in $\mathrm{mM}$ ): $120 \mathrm{CsCH}_{3} \mathrm{SO}_{3}, 20$ HEPES, 0.4 EGTA, $2.8 \mathrm{NaCl}, 5 \mathrm{~N}\left(\mathrm{CH}_{2} \mathrm{CH}_{3}\right)_{4} \mathrm{Cl}, 2.5 \mathrm{Mg}$-ATP, and $0.25 \mathrm{Mg}$-GTP, pH 7.3. Putative DA cells were identified by the presence of a large hyperpolarization-activated potassium current, $I_{\mathrm{h}}$ (Lacey et al., 1990; Johnson and North, 1992). According to previous studies, $I_{\mathrm{h}}$ is present in $84 \%$ of VTA DA neurons (Sarti et al., 2007), and there is general agreement that GABAergic neurons do not have $I_{\mathrm{h}}$ (Margolis et al., 2006). Although the presence of an $I_{\mathrm{h}}$ current does not unequivocally identify DA cells, it is likely that the contribution of $I_{\mathrm{h}}$-positive tyrosine hydroxylase-negative cells to the observed effects is very small. A bipolar stimulating electrode was placed rostrally at a distance of $100-300 \mu \mathrm{m}$ from the recording electrode. Afferents were stimulated at $0.1 \mathrm{~Hz}$, and the evoked EPSCs were filtered at $2 \mathrm{kHz}$, digitized at $5-10 \mathrm{kHz}$, and recorded using Igor Pro software (WaveMetrics).

NMDAR or AMPAR traces were constructed by averaging 15 EPSCs elicited at $+40 \mathrm{mV}$ and $-70 \mathrm{mV}$, respectively. NMDAR responses were calculated by subtracting the average response in the presence of $50 \mu \mathrm{M}$ D-2-amino-5-phosphonovalerate (D-APV) (AMPAR-mediated only) from that recorded in its absence. For LTP experiments, evoked EPSPs were recorded from neurons current clamped at $-70 \mathrm{mV}$ using 3-5 $\mathrm{M} \Omega$ electrodes filled with a potassium methanesulfonate solution containing the following: $0.95 \% \mathrm{KOH}(\mathrm{v} / \mathrm{v}), 0.76 \%$ methanesulfonic acid $(\mathrm{v} / \mathrm{v})$, $0.18 \%$ hydrochloric acid (v/v), 20 mM HEPES, 0.2 mM EGTA, $2.8 \mathrm{~mm}$ $\mathrm{NaCl}, 2.5 \mathrm{mg} / \mathrm{ml} \mathrm{MgATP}$, and $0.25 \mathrm{mg} / \mathrm{ml} \mathrm{GTP}$, pH 7.3. LTP was induced by using a spike-timing-dependent (STD) protocol as previously described (Liu et al., 2005): 20 bursts of EPSP-spike pairs were delivered, with each burst consisting of five paired stimuli delivered at $10 \mathrm{~Hz}$ (interburst interval of $5 \mathrm{~s}$ ). The postsynaptic spikes were evoked $\sim 5 \mathrm{~ms}$ after the onset of EPSPs by injecting depolarizing current pulses (1-2 nA, 3 $\mathrm{ms})$. All recordings with a stable $10 \mathrm{~min}$ baseline were included. The magnitude of LTP was computed by averaging 30 consecutive EPSPs 5 min before and $30 \mathrm{~min}$ after the end of the induction protocol unless otherwise indicated.

In experiments involving in vivo drug exposure, rats were weighed, injected with cocaine $(15 \mathrm{mg} / \mathrm{kg}$, i.p.) or equal amount of $0.9 \%$ saline, and then returned to their home cage for 2 or $\sim 23 \mathrm{~h}$, after which VTA slices were prepared. Thus, whole-cell recordings started at $3-5$ or $\sim 24 \mathrm{~h}$ after cocaine or saline administration. In experiments involving in vitro drug exposure, VTA slices were normally prepared and after recovery were incubated with test substances (10-30 min as indicated). After this treatment, slices were transferred (twice) in a beaker containing regular aCSF for complete washout of the drugs and allowed to recover for $2-4 \mathrm{~h}$. Thus, whole-cell recordings started $3-5 \mathrm{~h}$ after the end of drug exposure.

For experiments of rectification, spermine $(100 \mu \mathrm{M})$ was added to the intracellular solution. The rectification indices (RIs) were calculated by plotting the magnitude of the average EPSCs at $-70,0$, and $+40 \mathrm{mV}$ and taking the ratio of the slope of the lines connecting values at $0-40$ and at -70 to $0 \mathrm{mV}$ as previously described (Adesnik and Nicoll, 2007). Neurons were held at each potential for $2 \mathrm{~min}$ (12 sweeps) in the presence of D-APV. Picrotoxin, cocaine, $R-(+)-7$-chloro-8-hydroxy-3-methyl-1phenyl-2,3,4,5-tetrahydro-1 H-3-benzazepine (SCH-23390), ( \pm )-6chloro-7,8-dihydroxy-1-phenyl-2,3,4,5-tetrahydro-1 $\mathrm{H}$-3-benzazepine hydrobromide (SKF-81297), anisomycin, cycloheximide, spermine, and 1-naphthyl acetyl spermine (NASPM) were all purchased from Sigma. D-APV was from Tocris Bioscience, and philantotoxin-74 (PhTx-74) was kindly provided by Dr. P. M. England (University of California, San Francisco, San Francisco, CA). Three- to four-week-old mice lacking functional $\mathrm{D}_{5}$ dopamine receptors were a generous gift from Dr. D. R. Sibley (National Institute of Neurological Disorders and Stroke/National Institutes of Health, Bethesda, MD). $\mathrm{D}_{5}$ knock-out mice $\left(\mathrm{D}_{5}-/-\right)$ and wild-type littermates $\left(D_{5}+/+\right)$ were generated as previously described (Hollon et al., 2002).

\section{Results}

\section{Exposure to cocaine in vivo induces AMPAR potentiation within $3 \mathrm{~h}$}

Most studies on cocaine-induced changes at glutamatergic synaptic plasticity in the VTA were performed $24 \mathrm{~h}$ after in vivo exposure to the drug (Ungless et al., 2001; Borgland et al., 2004; Bellone and Lüscher, 2006). Cocaine administered intraperitoneally is rapidly distributed into the brain, reaching a maximum concentration within $30 \mathrm{~min}$ (Pan and Hedaya, 1998). Thus, we tested the effect of a single dose of cocaine at an earlier time point by preparing midbrain slices $2 \mathrm{~h}$ after intraperitoneal injection of cocaine $(15 \mathrm{mg} / \mathrm{kg})$ or equivalent volume of saline in juvenile rats and then waiting another $1-3 \mathrm{~h}$ before making whole-cell voltage clamp recordings; results are therefore collected $3-5 \mathrm{~h}$ after the in vivo injection. We observed that saline-injected rats showed a trend toward higher AMPAR/NMDAR ratios than naive rats, which is consistent with previous reports (Saal et al., 2003), because the injection procedure could represent an acute stressful event for a naive animal. Most notably, we observed a significant enhancement of the AMPAR/NMDAR ratio in the cocainetreated rats compared with the saline-treated or naive animals $(0.842 \pm 0.112, n=9 ; 0.429 \pm 0.070, n=5 ; 0.289 \pm 0.016, n=$ 5 , respectively; $p<0.01$ ) (Fig. 1), the magnitude of which was comparable to that observed at $24 \mathrm{~h}$ after cocaine in rats (Borgland et al., 2004). These results suggest that cocaineinduced LTP in the VTA occurs rapidly within $3 \mathrm{~h}$ of the cocaine administration and persists for at least 5 but less than $10 \mathrm{~d}$ (Ungless et al., 2001).

\section{Cocaine-induced LTP reduces subsequent induction of spike-timing-dependent LTP}

LTP in VTA DA cells can be induced by an STD protocol (Liu et al., 2005) and, surprisingly, was found to be enhanced after cocaine administration and not reduced as initially reported for LTP induction by a pairing protocol (Ungless et al., 2001). Thus, we next tested what effect in vivo cocaine-induced LTP has on the induction of STD LTP. VTA neurons from animals injected with saline $3-5 \mathrm{~h}$ earlier showed robust STD LTP $(142.0 \pm 8.4 \%$ of baseline at $30-35$ min after induction; LTP $>15 \%$ in 6 of 8 cells) 


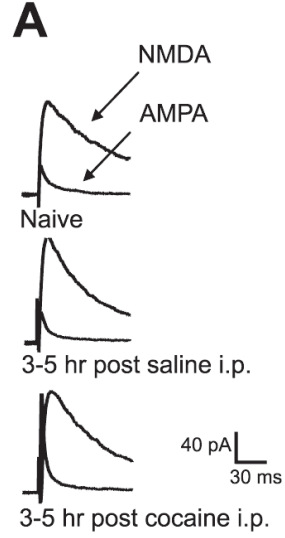

Figure 1. A single cocaine injection induces an increase in AMPAR/NMDAR ratio within $3 \mathrm{~h}$ in VTA neurons. $\boldsymbol{A}$, Representative traces of AMPAR and NMDAR EPSCs from naive animals or animals pretreated $3-5 \mathrm{~h}$ earlier with a single injection of cocaine $(15 \mathrm{mg} / \mathrm{kg}$, i.p.) or equivalent amount of saline. $\boldsymbol{B}$, Averaged AMPAR/NMDAR ratios. Cocaine-injected animals $(n=9)$ show a significantly increased ratio compared with saline-injected $(n=5)$ or naive $(n=5)$ animals. ${ }^{* *} p<0.01$. Error bars represent SEM.

(Fig. $2 \mathrm{~B}$ ) that was comparable to LTP in naive animals (147.4 \pm $6.7 \% ; p>0.05$; LTP $>15 \%$ in 7 of 9 cells) (Fig. $2 A$ ). In contrast, rats administered cocaine showed a significantly reduced LTP (114.1 $\pm 2.7 \%$; $p<0.01$; LTP $>15 \%$ in 3 of 12 cells) (Fig. $3 A$ ). On average, LTP was not inducible when tested $24 \mathrm{~h}$ after a single cocaine injection or $24 \mathrm{~h}$ after the fifth day of five consecutive injections $(99.0 \pm 3.5 \%$ and $93.1 \pm 10.7 \%$; LTP $>15 \%$ in 1 of 7 and 1 of 6 cells, respectively) (Fig. $2 D, E$ ). In agreement with previous results from mice (Ungless et al., 2001) (but see Liu et al., 2005), these results indicate that in vivo cocaine exposure causes a decrease in the incidence of electrically induced LTP in VTA DA neurons independent of the induction protocol and suggest that cocaine-induced LTP and synaptically evoked LTP share some common underlying mechanisms.

\section{Cocaine exposure induces AMPAR potentiation locally within the VTA}

Cocaine microinjected locally into the VTA is sufficient to induce locomotor sensitization in the rat (Cornish and Kalivas, 2001). Several studies indicate that the initial phase of this behavior correlates with the strengthening of glutamatergic synapses in the VTA (Kauer and Malenka, 2007). Together these findings suggest that cocaine acts locally within this structure to trigger neuroplasticity. To address this issue, we tested whether exposing a midbrain slice to cocaine in vitro would produce AMPAR-mediated LTP 3-5 h later in a manner similar to that which occurred after in vivo exposure. Recordings performed $3-5 \mathrm{~h}$ after a short incubation of slices with cocaine ( $5 \mu \mathrm{M}, 10 \mathrm{~min})$ or equivalent amount of vehicle (water, $10 \mathrm{~min}$ ) showed that cocaine-treated slices have a significantly higher AMPAR/NMDAR ratio compared with vehicle-treated or control slices recorded $1-2 \mathrm{~h}$ after slicing $(0.721 \pm 0.045, n=9 ; 0.321 \pm 0.043, n=7$; and $0.340 \pm 0.036$, $n=10$, respectively; $p<0.01$ ) (Fig. $3 B$ ). In contrast, when cocaine was applied directly in the recording chamber and AMPAR/ NMDAR ratios were assayed only $10 \mathrm{~min}$ after washout of the drug, the ratio was significantly reduced compared with timematched controls $(0.196 \pm 0.021, n=5, p<0.05$; and $0.348 \pm$ $0.047, n=5, p<0.05$; data not shown). This is in agreement with previous observations that acute cocaine perfused onto midbrain slices causes a potentiation of NMDAR- but not AMPAR- mediated synaptic transmission in VTA neurons a few minutes after washout of the drug (Schilström et al., 2006). These results suggest that cocaine can act locally within the VTA to slowly elicit LTP of AMPAR transmission.

Ex vivo data suggest that NMDAR activation in the VTA during acute cocaine exposure is required for the AMPAR/NMDAR ratio increase (Ungless et al., 2001). However, in this previous study, NMDAR antagonists were injected systemically. We therefore directly tested whether NMDARs within the VTA were required for the cocaine-induced LTP in VTA DA cells by preincubating VTA slices with D-APV $(50 \mu \mathrm{M}) 5$ min before and during cocaine. Under these conditions the cocaine-induced enhancement of the AMPAR/NMDAR ratio was prevented (0.414 \pm 0.08 ; $n=9 ; p<0.01$ ) (Fig. $3 B$ ), directly demonstrating that NMDAR activation within the VTA is required for the cocaine-induced LTP.

We next tested whether STD LTP was inducible under these same in vitro conditions. Ten minutes after cocaine washout (5 $\mu \mathrm{M}$ for $10 \mathrm{~min}$, applied in the recording chamber), LTP could be elicited using an STD protocol (120.5 $\pm 1.7 \%$; LTP $>15 \%$ in 8 of 11 cells; data not shown), but not $3-5$ h later $(100.0 \pm 3.2 \%$; LTP $>15 \%$ in 2 of 10 cells) (Fig. $3 D$ ), results that are consistent with those observed ex vivo. In contrast, when slices were incubated with vehicle alone or with D-APV before and during cocaine exposure, LTP was inducible $(125.8 \pm 8.4 \%$, LTP $>15 \%$ in 5 of 5 cells; and $26.1 \pm 2.8 \%$, LTP $>15 \%$ in 6 of 7 cells, respectively) (Fig. 3C,E). Together, these data suggest that cocaine acting within the VTA leads to the strengthening of AMPAR transmission via activation of NMDARs within the VTA, and that this cocaine-induced LTP shares mechanisms with STD LTP.

\section{Cocaine-induced LTP is mediated by $D_{5}$ receptors}

Because cocaine blocks DA transporters and increases DA extracellular concentration, its pharmacological effects could be mediated by increased activation of DA receptors, which are Gscoupled $\mathrm{D}_{1}$-like $\left(\mathrm{D}_{1}\right.$ and $\left.\mathrm{D}_{5}\right)$ and Gi-coupled $\mathrm{D}_{2}$-like $\left(\mathrm{D}_{2}, \mathrm{D}_{3}\right.$, and $\mathrm{D}_{4}$ ). Repeated intra-VTA microinjections of a $\mathrm{D}_{1}$-like $\mathrm{DA}$ agonist mimic the sensitization process produced by repeated cocaine administration (Pierce et al., 1996). Thus, we directly tested in vitro the role of DA receptor activation in cocaine-induced LTP in the VTA. Incubation of slices 5 min before and during cocaine exposure with the specific $\mathrm{D}_{1} / \mathrm{D}_{5}$ receptor antagonist $\mathrm{SCH}-23390$ $(10 \mu \mathrm{M})$ prevented the AMPAR/NMDAR ratio increase $(0.340 \pm$ $0.033 ; n=5 ; p<0.01$ ) (Fig. $4 A$ ), whereas the $\mathrm{D}_{2}$ receptor antagonist eticlopride $(3 \mu \mathrm{M})$ did not $(0.713 \pm 0.143 ; n=5 ; p>0.05)$. We then tested the ability of the selective $D_{1} / D_{5}$ receptor agonist SKF-81297 to mimic cocaine-induced LTP. VTA neurons from slices exposed to SKF-81297 (10 $\mu \mathrm{M}, 10 \mathrm{~min})$ showed a significant increase of the AMPAR/NMDAR ratio when recorded 3-5 h $(0.906 \pm 0.159 ; n=10 ; p<0.01)$ (Fig. $4 A$ ) but not $15-30 \mathrm{~min}$ $(0.221 \pm 0.033 ; n=5 ; p>0.05$; data not shown) after washout of the drug compared with vehicle-treated cells recorded at matching times. Coincubation with D-APV $(50 \mu \mathrm{M}) 5 \mathrm{~min}$ before and during SKF-81297 significantly reduced the AMPAR/NMDAR ratio increase $(0.499 \pm 0.106 ; n=7 ; p<0.01)$ (Fig. $4 A$ ). These data suggest that cocaine acts via $D_{1}$-like receptors to initiate the delayed strengthening of AMPAR transmission and that activation of NMDARs is required during induction.

Given that anatomical evidence indicates that $D_{5}$ but not $D_{1}$ receptors are expressed in the soma of DA VTA neurons (Ciliax et al., 2000; Khan et al., 2000), we hypothesized that the effects of cocaine on AMPAR transmission are mediated by the $\mathrm{D}_{5}$ receptor. Because there are no available antagonists to distinguish be- 

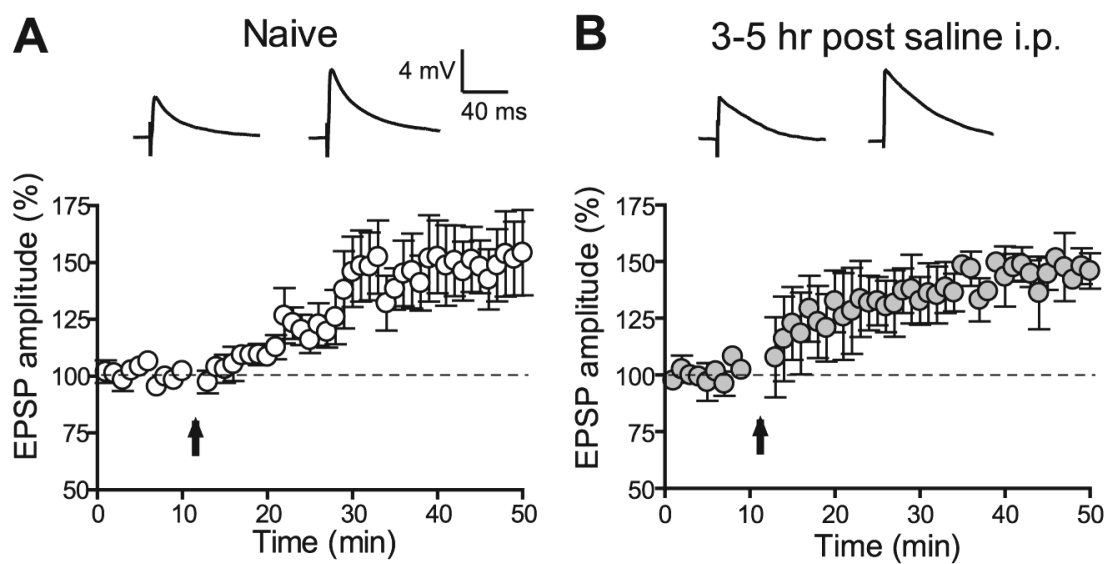

\section{C $\quad 3-5 \mathrm{hr}$ post cocaine i.p.}
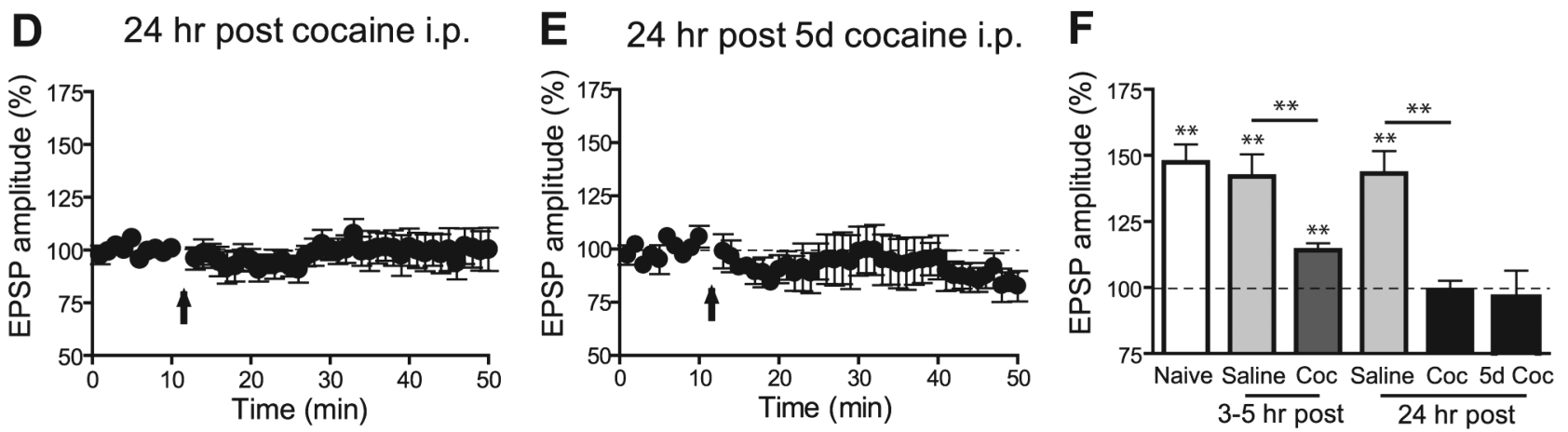

Figure 2. Previous exposure to cocaine in vivo reduces the incidence of STD LTP in VTA neurons. $A-E$, Time course of mean EPSPs before and after the STD LTP induction protocol indicated by the arrow in naive animals $(\boldsymbol{A} ; n=9)$, animals injected $3-5$ h earlier with saline $(\boldsymbol{B} ; n=8)$ or cocaine $(15 \mathrm{mg} / \mathrm{kg}$, i.p.; $\boldsymbol{C} ; n=12)$, and animals injected $24 \mathrm{~h}$ earlier with one injection of cocaine $(15 \mathrm{mg} / \mathrm{kg}$, i.p.; $\boldsymbol{D} ; n=6)$ or the last injection of five daily cocaine injections $(15 \mathrm{mg} / \mathrm{kg}$, i.p.; $\boldsymbol{E} ; n=6)$. $\boldsymbol{A}-\boldsymbol{C}$, Representative EPSP traces before and $30 \mathrm{~min}$ after the induction protocol are shown above graphs. $F$, Summary of the magnitude of LTP under various conditions showing a significant reduction of LTP in cocaine-treated animals compared with time-matched saline-treated animals. Coc, Cocaine. $*^{* *} p<0.01$. Error bars represent SEM.

tween $\mathrm{D}_{1}$ and $\mathrm{D}_{5}$ receptors, to examine this possibility directly we tested the effect of cocaine in $\mathrm{D}_{5}$ receptor knock-out mice $\left(\mathrm{D}_{5}-/-\right)$ and wild-type littermates $\left(\mathrm{D}_{5}+/+\right) . \mathrm{D}_{5}$ mutant mice did not show an increase in the AMPAR/NMDAR ratio when recorded 3-5 h after an acute cocaine injection ( $15 \mathrm{mg} / \mathrm{kg}$, i.p.) compared with wild-type mice $(0.307 \pm 0.024, n=5$ and $0.558 \pm$ $0.091, n=4$, respectively; $p<0.05$; data not shown). These results suggest that $D_{5}$ receptor activation is essential for the cocaine-induced LTP in VTA DA neurons.

Cocaine-induced LTP requires protein synthesis

The delayed development and the persistence of AMPAR potentiation after cocaine exposure might suggest that the synthesis of a new protein is involved, similarly to what happens in the late and long-lasting phase of hippocampal LTP (Stanton and Sarvey, 1984; Frey et al., 1988). When the mRNA translation inhibitor anisomycin $(40 \mu \mathrm{M})$ was preincubated $20 \mathrm{~min}$ before and during cocaine exposure, the AMPAR/NMDAR ratio increase $3-5 \mathrm{~h}$ later was blocked $(0.348 \pm 0.056 ; n=9 ; p<0.01$ compared with cocaine) (Fig. $4 B$ ). Conversely, when anisomycin was applied with a delay of $1 \mathrm{~h}$ from cocaine washout, AMPAR/NMDAR ratios were still increased to values comparable to those from vehicle-treated cells $(0.645 \pm 0.092 ; n=9 ; p>0.05)$, whereas anisomycin alone did not significantly affect AMPAR/NMDAR ratio $(0.384 \pm 0.039 ; n=4 ; p>0.05)$. All experiments with anisomycin were repeated using cycloheximide $(100 \mu \mathrm{M})$, and similar results were obtained (data not shown). Together these data suggest that similar to late-phase LTP in the hippocampus, cocaine-induced LTP in the VTA depends on transient upregulation of protein synthesis during the induction phase (drug exposure).

\section{Cocaine induces a switch in AMPAR subunit composition}

It is interesting to consider what proteins are being synthesized that might be responsible for the change in synaptic strength recorded as early as $3 \mathrm{~h}$ after cocaine. Incorporation of specific subunit-containing AMPARs seems to be essential in several forms of synaptic plasticity, including LTP (Liu and Cull-Candy, 2000; Plant et al., 2006) (but see Adesnik and Nicoll, 2007). AMPARs are heterotetramer assemblies of four subunits, GluR1GluR4. The receptors lacking the GluR2 subunit are permeable to $\mathrm{Ca}^{2+}$ and $\mathrm{Zn}^{2+}$ and are blocked by intracellular polyamines such as spermine at positive potentials, which generates a characteristic inwardly rectifying current-voltage $(I-V)$ relationship (Jonas and Burnashev, 1995; Kamboj et al., 1995).

$\mathrm{D}_{1}$-like receptor activation has been reported to stimulate local protein synthesis of GluR1 and its insertion at synaptic sites in cultured hippocampal neurons (Smith et al., 2005). Moreover, recent evidence reveals that VTA synapses in young mice show insertion of GluR2-lacking receptors $24 \mathrm{~h}$ after a single cocaine injection (Bellone and Lüscher, 2006).

To test for a cocaine-induced switch in AMPAR subunit composition in VTA DA neurons, we examined the $I-V$ relationships of EPSCs and calculated RIs with $100 \mu \mathrm{M}$ spermine in the recording electrode (see Materials and Methods). We found that neurons exposed briefly to cocaine 3-5 h earlier showed decreased 
RIs compared with vehicle-exposed cells (0.986 $\pm 0.056, n=11$ and $0.678, n=7$, respectively; $p<0.05$ ) (Fig. $5 A$ ). We also measured AMPAR/NMDAR ratios in the presence of intracellular spermine. Under these conditions, the average ratio from cocaine-exposed neurons is not significantly different from vehicle-treated neurons $(0.711 \pm 0.128, n=8$ and $0.612 \pm$ $0.129, n=10$, respectively; $p>0.05$ ) (supplemental Fig. 1, available at www.jneurosci.org as supplemental material), suggesting that the increase in AMPAR-mediated transmission after cocaine is indeed mediated by GluR2-lacking receptors.

Surprisingly we observed that control AMPAR/NMDAR ratios measured in the presence of spermine are higher then in its absence. However, this result is in agreement with previous observations that intracellular spermine also reduced NMDAR-mediated currents at positive membrane potentials (Turecek et al., 2004).

As a further test for changes in AMPAR subunit composition after cocaine, we evaluated the effects of PhTx-74, a compound that has the unique property of being a use-dependent blocker of homomeric and heteromeric GluR1-containing AMPARs (Nilsen and England, 2007). After bath application of PhTx-74 (100 $\mu \mathrm{M})$, a short period of high-frequency stimulation $(10 \mathrm{~Hz}, 2 \mathrm{~min})$ was applied to allow the binding of the toxin to the open conformation of AMPA channels. AMPAR EPSCs from VTA cells treated 3-5 h earlier with cocaine showed increased sensitivity to bath application of PhTx-74 compared with vehicle-treated cells (residual current $63.0 \pm 4.0 \%, n=8$, and $74.0 \pm 3.7 \%, n=$ 8 , respectively; $p<0.05$ ) (Fig. $5 B, D$ ), suggesting an increased contribution of GluR1-containing AMPARs to synaptic transmission after cocaine. To distinguish between the contributions of GluR2lacking and GluR2-containing receptors, we tested the sensitivity of EPSCs to bath application of NASPM (7.5 $\mathrm{min}, 100 \mu \mathrm{M}$ ), a selective blocker of calcium-permeable GluR2lacking AMPARs. The size of residual AMPAR EPSCs after NASPM perfusion was significantly smaller in cells exposed $3-5 \mathrm{~h}$ earlier to cocaine in vitro compared with vehicle $(74.1 \pm 3.3 \%, n=7$ and $93.8 \pm 2.3 \%, n=7$, respectively; $p<0.01$ ) (Fig. $5 C, D$ ), or to cocaine in vivo compared with saline $(79.01 \pm 4.2, n=7$ and $91.9 \pm 1.8, n=$ 5 , respectively; $p<0.01$, data not shown), revealing a switch toward higher levels of GluR1/1 and/or GluR1/3 in VTA DA synaptic membranes induced by cocaine. Similar changes have been observed at $24 \mathrm{~h}$ after cocaine injection (Bellone and Lüscher, 2006); our results demonstrate that this switch occurs rapidly within $3 \mathrm{~h}$ and by local action of cocaine within the VTA.

We further show that the insertion of GluR2-lacking receptors is a common underlying mechanism shared both by cocaineinduced LTP and synaptically evoked LTP. As shown in Figure 6,
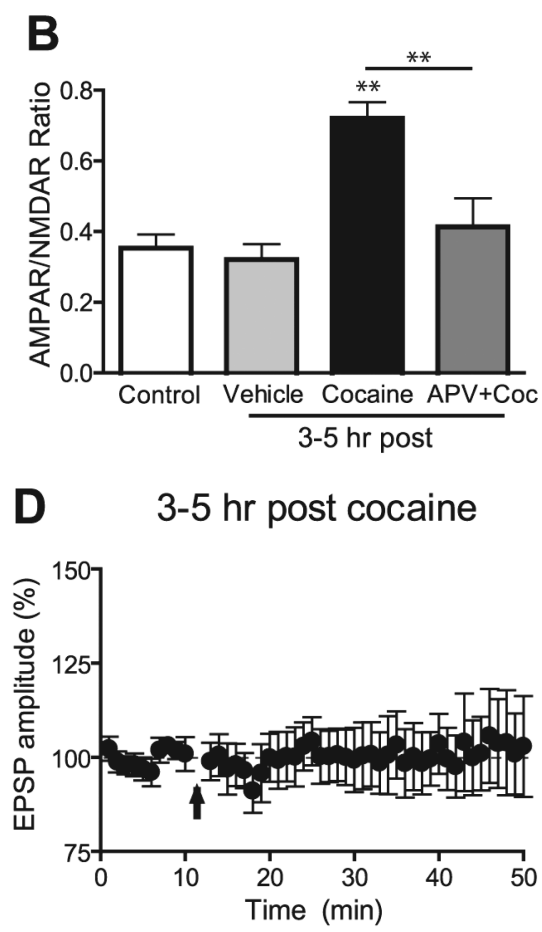

$\mathbf{F}$

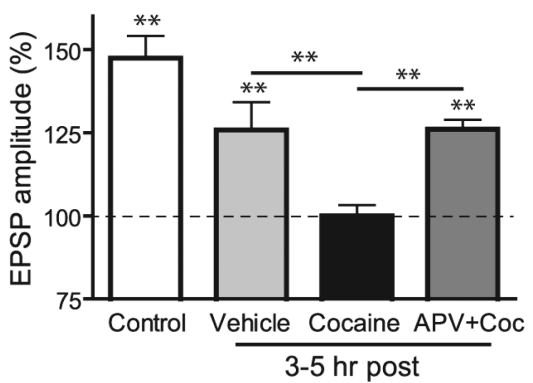

3-5 hr post

Figure 3. Brief exposure to cocaine in vitro induces $3-5 \mathrm{~h}$ later an NMDAR-dependent increase in AMPAR/NMDAR ratio and a reduction the incidence of STD LTP in VTA neurons. $\boldsymbol{A}$, Schematic of the experimental design. $\boldsymbol{B}$, Averaged AMPAR/NMDAR ratios. slices $(n=7)$, control slices $(n=10)$, and slices treated with APV 5 min before and during cocaine $(n=9)$. $\boldsymbol{C}-\boldsymbol{E}$, Time course of $10 \mathrm{~min} ; \boldsymbol{D} ; n=10)$, or D-APV $(50 \mu \mathrm{m})$ before and during cocaine $(\boldsymbol{E} ; n=7)$. $\boldsymbol{F}$, Summary of the magnitude of LTP under various conditions showing a significant reduction of LTP in cocaine-treated slices compared with vehicle-treated slices and slices in which NMDAR was blocked during cocaine. Coc, Cocaine. ${ }^{* *} p<0.01$. Error bars represent SEM.

$A$ and $B$, potentiated EPSPs are reduced to baseline levels after NASPM bath application $(140 \pm 3.9 \%$ at $25-30$ min after LTP induction and $96.5 \pm 5.4 \%$ at $0-5$ min after NASPM exposure; $n=4 ; p<0.01)$.

\section{Discussion}

Time course of cocaine-induced LTP

Acutely perfused cocaine on VTA slices enhances NMDAR currents and leaves AMPAR transmission unaffected. Although such potentiation can be measured within a few minutes after cocaine washout, its duration is unknown (Schilström et al., 2006). On the other hand, $24 \mathrm{~h}$ after an intraperitoneal injection of cocaine, AMPAR transmission is potentiated for many days (Borgland et al., 2004). NMDAR transmission does not appear to be affected at this time, but enhancement of AMPAR EPSCs is blocked when NMDAR antagonists are injected before cocaine (Ungless et al., 
A

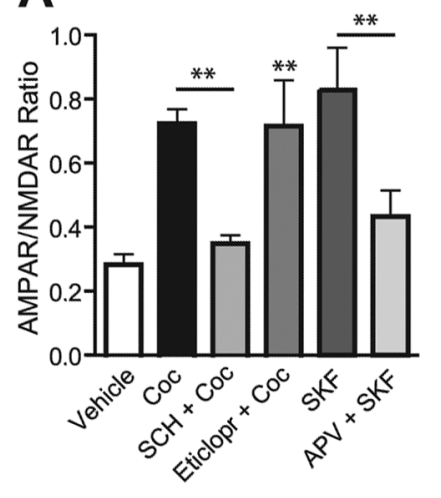

B

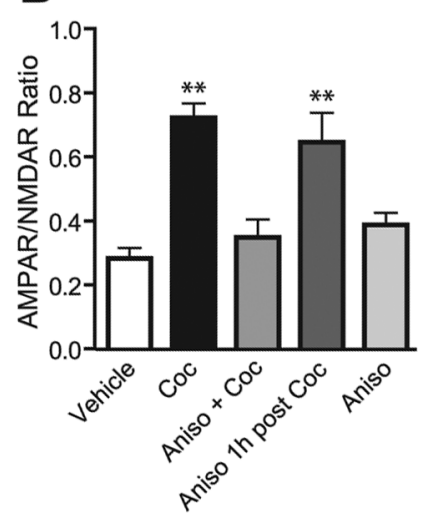

Figure 4. Cocaine-induced increase in AMPAR/NMDAR ratio in vitro is mediated by $D_{5}$ receptors and requires protein synthesis during induction. $A, B$, Averaged AMPAR/NMDAR ratios recorded $3-5 \mathrm{~h}$ after bath incubation with different drugs. $A$, Cocaine-induced LTP was prevented by treatment 5 min before and during cocaine with $\mathrm{D}_{1}$ antagonist $\mathrm{SCH}-23390(10 \mu \mathrm{m}$; $n=5)$ but not with $\mathrm{D}_{2}$ antagonist eticlopride $(3 \mu \mathrm{m} ; n=5)$. The $\mathrm{D}_{1}$ agonist SKF-81297 $\left(10 \mu \mathrm{m}_{;}\right.$ $n=10)$ alone increases the ratio, but not in the presence of $\mathrm{D}-\mathrm{APV}(50 \mu \mathrm{m} ; n=7)$. B, Cocaineinduced LTP was prevented when the protein synthesis inhibitor anisomycin $(40 \mu \mathrm{m} ; n=9)$ was incubated 20 min before and during cocaine, but not $1 \mathrm{~h}$ after $(n=9)$. Coc, Cocaine; $\mathrm{SCH}$ SCH-23390; Eticlopr, eticlopride; SKF, SKF-81297; Aniso, anisomycin. ${ }^{* *} p<0.01$. Error bars represent SEM.

2001). Given that multiple signaling cascades are likely initiated in intact animals $1 \mathrm{~d}$ after cocaine exposure, it is unclear whether these are consecutive stages of the same LTP-like phenomenon. Here we show that AMPAR EPSCs on VTA DA synapses are potentiated as early as $3 \mathrm{~h}$ after a single cocaine injection. Surprisingly, similar results were obtained in vitro, where a brief application of cocaine does not enhances AMPAR/NMDAR ratios in DA neurons within 30 min of washout of the drug, but a significant increase was observed within 3-5 h. Thus, cocaine acts locally within the VTA to induce a delayed LTP of AMPAR transmission and does not require an intact circuitry.

This finding allowed us to use pharmacological manipulations to investigate underlying mechanisms. We show that NMDAR activation is an early necessary event for the delayed LTP, because the presence of NMDAR antagonists before and during cocaine application prevented it. This also suggests that a glutamatergic tone sufficient to activate NMDARs on VTA neurons in the absence of stimulation must be present in the slice during cocaine exposure.

Previous studies showed that $2 \mathrm{~h}$ after in vivo injection of amphetamine increased the AMPAR/NMDAR ratio in VTA neurons, whereas an in vitro exposure failed to do so (Faleiro et al., 2004). The more robust increase in extracellular DA by amphetamine might engage different neuroadaptations (Ritz et al., 1987; Seiden et al., 1993). Moreover, amphetamine was continuously applied for 105-180 min, whereas we performed a $10 \mathrm{~min}$ incubation with cocaine followed by a long drug-free period. Thus, we hypothesize that cocaine-induced enhancement of NMDAR transmission is the first step leading to the delayed LTP that develops during cocaine withdrawal. Indeed, in vitro cocaine increases NMDAR EPSCs only after washout of the drug (Schilström et al., 2006).

Cocaine-induced LTP is mediated via $D_{5}$ receptor activation We show that activation of $\mathrm{D}_{1}$-like receptors is required for cocaine-induced LTP in VTA neurons, because preincubation with a $D_{1}$ antagonist prevented it, whereas $D_{1}$ agonists mimicked cocaine-mediated LTP. The plasticity might be caused by direct activation of $\mathrm{D}_{1}$ receptors expressed on DA neurons, but presynaptic $\mathrm{D}_{1}$ receptors on non-DA cells (Lu et al., 1997) might contribute to the effect. Indeed, $\mathrm{D}_{1}$ agonists microinjected into the VTA increase local release of neurotransmitters, including glutamate (Kalivas and Duffy, 1995). Although this mechanism might be important in vivo, an acute presynaptic action of cocaine is unlikely in vitro, because no acute cocaine-mediated increase of AMPAR EPSCs was recorded in slices (Schilström et al., 2006). Moreover, SKF-81297 and cocaine perfusion cause a rapid increase of NMDAR EPSCs on VTA neurons that was blocked by inclusion in the recording pipette of PKA inhibitors (Schilström et al., 2006). Thus, we propose that activation of postsynaptic $D_{1}$ receptors on DA cells directly activates intracellular pathways leading to modulation of NMDARs. Consistent with a critical role for $\mathrm{D}_{1}$ receptors in cocaine-induced plasticity are the findings that repeated intra-VTA perfusions with $\mathrm{D}_{1}$ agonists mimic the sensitization process produced by repeated cocaine exposure (Pierce et al., 1996) and that VTA $\mathrm{D}_{1}$ but not $\mathrm{D}_{2}$ receptors play a critical role in induction of locomotor sensitization to amphetamine (Vezina, 1996).

Because VTA DA neurons appear to express somatic $D_{5}$ but not $D_{1}$ receptors, it is likely that $D_{5}$ receptors mediate the action of cocaine (Yung et al., 1995; Ciliax et al., 2000; Khan et al., 2000), a suggestion supported by the lack of effect of cocaine in $\mathrm{D}_{5}-/-$ mice.

\section{Cocaine-induced LTP requires new protein synthesis}

Our data provide evidence that cocaine-induced LTP in the VTA requires transient upregulation of protein synthesis. Similarly, a $\mathrm{D}_{1}$ receptor-dependent LTP has been described in hippocampal slices, in which a short incubation with $\mathrm{D}_{1}$ agonists induces a delayed-onset LTP that requires NMDAR activation and new protein synthesis (Huang and Kandel, 1995; Navakkode et al., 2007).

We show that protein synthesis inhibitors blocked VTA LTP when applied during the induction phase (drug exposure) and not $1 \mathrm{~h}$ later. A similar time window for protein synthesis requirement has been observed in late LTP in the CA1 (Fonseca et al., 2006).

It is now well established that local dendritic protein synthesis and degradation play an important role in long-term synaptic plasticity (Sutton and Schuman, 2006; Bramham and Wells, 2007). Although the identity and role of local dendritic protein synthesized after LTP induction remain largely to be established, levels of ribosomal factors, transcription factors, or components of the induction cascade for synaptic plasticity have been shown to rapidly increase after LTP induction (Steward and Schuman, 2001; Eberwine et al., 2002). Importantly, it has recently been shown that rapid local protein synthesis in response to activation of the mTOR (mammalian target of rapamycin) pathway underlies glutamatergic plasticity at VTA synapses (Mameli et al., 2007). This study suggests that specific AMPAR subunits are among the newly translated proteins sustaining LTD expression. Similar events could play a role in cocaine-induced LTP.

\section{Cocaine induces a switch in AMPAR subunit composition}

Stable incorporation of AMPARs in the synaptic membrane characterizes potentiated synapses (Malinow and Malenka, 2002; Bredt and Nicoll, 2003), and there are conflicting results as to whether a switch in the subunit composition of AMPARs is required to sustain LTP (Clem and Barth, 2006; Plant et al., 2006; Adesnik and Nicoll, 2007; Kopec et al., 2007). 
Recent evidence revealed higher levels of GluR2-lacking receptors in VTA synapses $24 \mathrm{~h}$ after cocaine (Bellone and Lüscher, 2006). We observed that their contribution to AMPAR-mediated transmission is increased as early as $3 \mathrm{~h}$ after cocaine exposure. In control conditions, $\sim 25 \%$ of AMPAR EPSCs are blocked by PhTx-74 and not by NASPM and therefore are mediated by GluR1/2-containing channels, whereas GluR2-lacking channels contribute minimally. After cocaine exposure, the sensitivity to both drugs increases significantly, indicating that cocaine induces synaptic insertion of GluR2-lacking AMPARs, not GluR2-containing AMPARs (blocked only by PhTx-74). However, if GluR1/1 and GluR1/3, which are blocked equally well by PhTx-74 and NASPM, are exclusively inserted after cocaine, then the increase in block should be the same for both compounds. Instead we observe an increase in block of $\sim 20 \%$ with NASPM and only of $\sim 10 \%$ by PhTx-74, thus suggesting that GluR1/2 receptors are replaced by receptors lacking the GluR2 subunits.

We propose that cocaine-induced LTP might be sustained, at least initially, by increased levels of synaptic highconductance GluR2-lacking AMPARs. $\mathrm{D}_{1}$ receptor activation may stimulate the synthesis of GluR1 subunits or other proteins implicated in their trafficking and/or stabilization. Indeed, $\mathrm{D}_{1}$ activation has been reported to induce an increase in the surface expression of GluR1-containing receptors in cultured nucleus accumbens and hippocampal neurons (Mangiavacchi and Wolf, 2004; Smith et al., 2005). Moreover, increased levels of GluR1-containing receptors on DA neurons in VTA-PFC cocultures have been reported after brief exposure to $\mathrm{D}_{1}$ agonists (Gao and Wolf, 2007). However, neither the relevance of these increases to synaptic function in slices or in vivo nor the potential role of NMDARs has been established.

Cocaine-induced LTP and synaptically induced LTP share

common mechanisms

In VTA slices, LTP can be induced by highfrequency afferent stimulation but is absent $24 \mathrm{~h}$ after in vivo cocaine administration, suggesting that the two forms of plasticity may share common underlying mechanisms (Ungless et al., 2001). However, STD LTP was reported to be enhanced after repeated cocaine injections (Liu et al., 2005). Here we found that the incidence of STD LTP was significantly reduced 3-5 h after a single injection of cocaine and $3-5 \mathrm{~h}$ after in vitro exposure, unless cocaine-induced LTP was prevented by coincubation with NMDAR inhibitors.

A

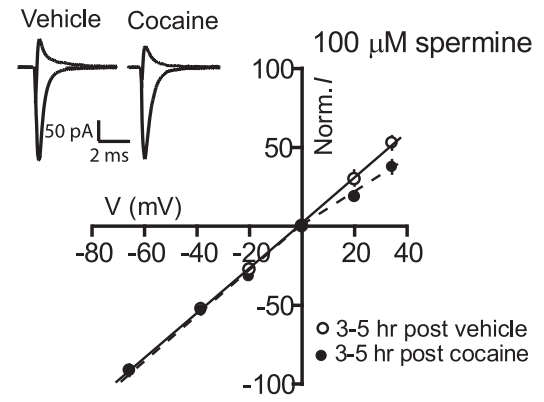

B
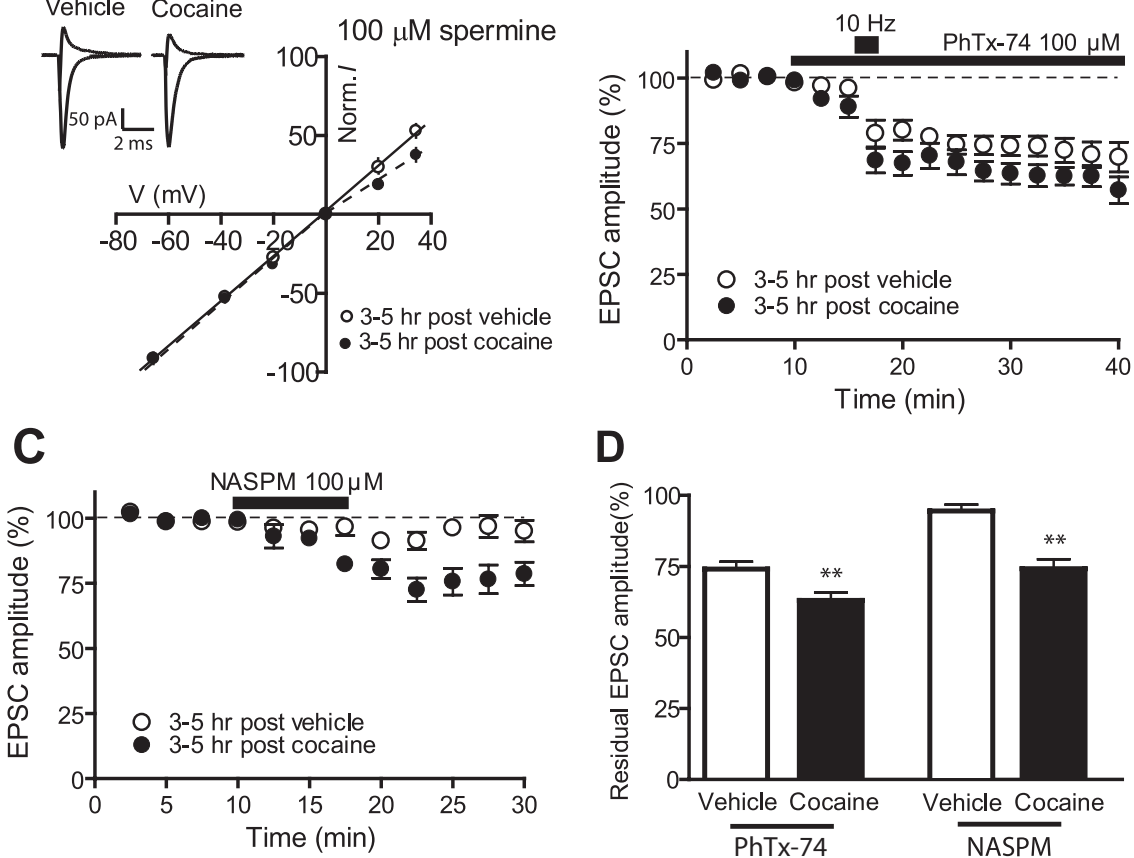

D

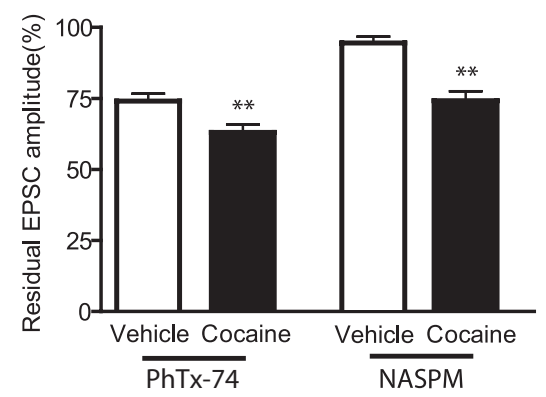

Figure 5. Brief exposure to cocaine triggers the insertion of GluR2-lacking AMPARs on VTA neurons within 3-5 h. $\boldsymbol{A}$, Average I-V plots from slices exposed 3-5 h earlier to vehicle $(n=11)$ or cocaine $(n=7) . A$, Inset, Representative traces recorded at -70 $\mathrm{mV}$ and $+40 \mathrm{mV}$ in the presence of $\mathrm{D}-\mathrm{APV}(50 \mu \mathrm{m})$ and with spermine $(100 \mu \mathrm{m})$ in the internal solution. $\boldsymbol{B}, \boldsymbol{D}$, Time course of EPSC amplitudes showing the effect of PhTx-74 (100 $\mu \mathrm{m}, 30 \mathrm{~min})$ on VTA neurons exposed $3-5$ h earlier with cocaine $(n=8)$ or vehicle $(n=8)(\boldsymbol{B})$ and summary of residual EPSCs measured $20-25$ min after drug perfusion $(\boldsymbol{D})$. The short bar in $\boldsymbol{B}$ indicates the period of high-frequency stimulation ( $10 \mathrm{~Hz}, 2 \mathrm{~min}$ ) that allows binding of the toxin to the open conformation of AMPA channels. $C, \boldsymbol{D}$, Time course of EPSC amplitudes showing the effect of NASPM (100 $\mu \mathrm{m}, 7.5 \mathrm{~min}$ ) on VTA neurons exposed 3-5 h earlier with cocaine $(n=7)$ or vehicle $(n=7)(\boldsymbol{C})$ and summary of residual EPSCs measured $15-20$ min after drug perfusion $(\boldsymbol{D})$. Norm., Normalized. ${ }^{* *} p<0.01$. Error bars represent SEM.
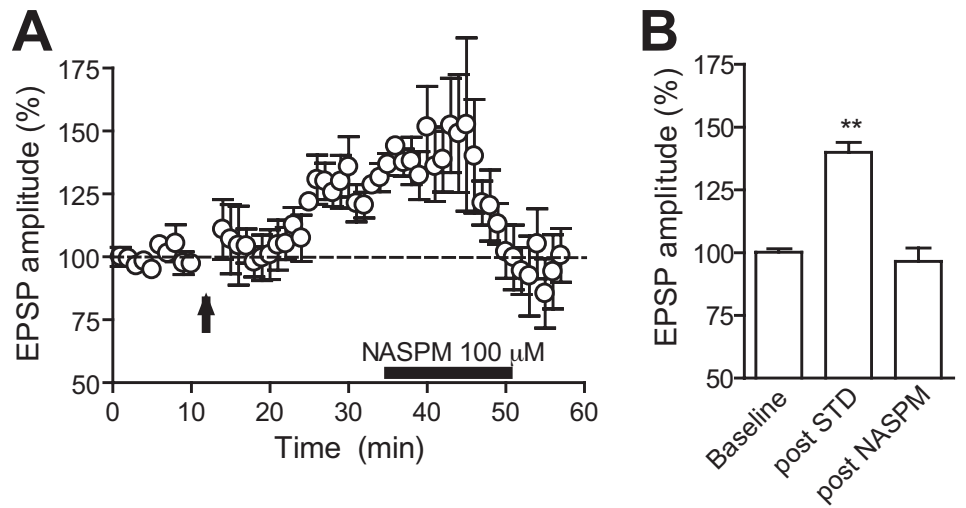

Figure 6. The expression of STD LTP is mediated by the insertion of GluR2-lacking AMPARs on VTA neurons. $\boldsymbol{A}$, Time course of mean EPSPs $(n=4)$ before and after the STD LTP induction protocol indicated by the arrow. The horizontal black bar represents the time of NASPM bath application (100 $\mu \mathrm{m}, 15 \mathrm{~min})$. $\boldsymbol{B}$, Summary of the magnitude of EPSPs in baseline, $25-30 \mathrm{~min}$ after LTP induction, and $0-5$ min after NASPM exposure. ${ }^{* *} p<0.01$. Error bars represent SEM.

We cannot unequivocally state whether the lack of LTP after cocaine is the result of occlusion caused by the synapses already being potentiated or rather by cocaine-induced inhibition of intracellular pathways required for LTP induction or expression. However, we show that both forms of LTP are associated with elevated synaptic levels of GluR2-lacking AMPARs. This might explain why once cocaine has triggered such switch in VTA neurons, highfrequency electrical stimulation fails to (further) induce LTP. 


\section{Conclusions}

Here we demonstrate that acute cocaine exposure within the VTA induces an NMDAR-dependent delayed potentiation of AMPAR-mediated synaptic transmission. We propose that cocaine increases extracellular dopamine concentration that directly binds $\mathrm{D}_{5}$ receptors onto DA neurons, causing a rapid and transient upregulation of NMDAR-mediated synaptic transmission. This appears to be a necessary step for the subsequent induction of long-lasting, protein synthesis-dependent LTP evident $\sim 3 \mathrm{~h}$ after cocaine exposure and sustained by increased levels of synaptic GluR1-containing AMPA receptors.

\section{References}

Adesnik H, Nicoll RA (2007) Conservation of glutamate receptor 2-containing AMPA receptors during long-term potentiation. J Neurosci 27:4598-4602.

Bellone C, Lüscher C (2006) Cocaine triggered AMPA receptor redistribution is reversed in vivo by mGluR-dependent long-term depression. Nat Neurosci 9:636-641.

Borgland SL, Malenka RC, Bonci A (2004) Acute and chronic cocaineinduced potentiation of synaptic strength in the ventral tegmental area: electrophysiological and behavioral correlates in individual rats. J Neurosci 24:7482-7490.

Bramham CR, Wells DG (2007) Dendritic mRNA: transport, translation and function. Nat Rev Neurosci 8:776-789.

Bredt DS, Nicoll RA (2003) AMPA receptor trafficking at excitatory synapses. Neuron 40:361-379.

Ciliax BJ, Nash N, Heilman C, Sunahara R, Hartney A, Tiberi M, Rye DB, Caron MG, Niznik HB, Levey AI (2000) Dopamine $\mathrm{D}_{5}$ receptor immunolocalization in rat and monkey brain. Synapse 37:125-145.

Clem RL, Barth A (2006) Pathway-specific trafficking of native AMPARs by in vivo experience. Neuron 49:663-670.

Cornish JL, Kalivas PW (2001) Repeated cocaine administration into the rat ventral tegmental area produces behavioral sensitization to a systemic cocaine challenge. Behav Brain Res 126:205-209.

Eberwine J, Belt B, Kacharmina JE, Miyashiro K (2002) Analysis of subcellularly localized mRNAs using in situ hybridization, mRNA amplification, and expression profiling. Neurochem Res 27:1065-1077.

Faleiro LJ, Jones S, Kauer JA (2004) Rapid synaptic plasticity of glutamatergic synapses on dopamine neurons in the ventral tegmental area in response to acute amphetamine injection. Neuropsychopharmacology 29:2115-2125.

Fonseca R, Nägerl UV, Bonhoeffer T (2006) Neuronal activity determines the protein synthesis dependence of long-term potentiation. Nat Neurosci 9:478-480.

Frey U, Krug M, Reymann KG, Matthies H (1988) Anisomycin, an inhibitor of protein synthesis, blocks late phases of LTP phenomena in the hippocampal CA1 region in vitro. Brain Res 452:57-65.

Gao C, Wolf ME (2007) Dopamine alters AMPA receptor synaptic expression and subunit composition in dopamine neurons of the ventral tegmental area cultured with prefrontal cortex neurons. J Neurosci 27:14275-14285.

Hollon TR, Bek MJ, Lachowicz JE, Ariano MA, Mezey E, Ramachandran R, Wersinger SR, Soares-da-Silva P, Liu ZF, Grinberg A, Drago J, Young WS 3rd, Westphal H, Jose PA, Sibley DR (2002) Mice lacking $\mathrm{D}_{5}$ dopamine receptors have increased sympathetic tone and are hypertensive. J Neurosci 22:10801-10810.

Huang YY, Kandel ER (1995) $D_{1} / D_{5}$ receptor agonists induce a protein synthesis-dependent late potentiation in the CA1 region of the hippocampus. Proc Natl Acad Sci U S A 92:2446-2450.

Johnson SW, North RA (1992) Two types of neuron in the rat ventral tegmental area and their synaptic inputs. J Physiol 450:455-468.

Jonas P, Burnashev N (1995) Molecular mechanisms controlling calcium entry through AMPA-type glutamate receptor channels. Neuron 15:987-990.

Jones S, Bonci A (2005) Synaptic plasticity and drug addiction. Curr Opin Pharmacol 5:20-25.

Kalivas PW, Duffy P (1995) D $\mathrm{D}_{1}$ receptors modulate glutamate transmission in the ventral tegmental area. J Neurosci 15:5379-5388.

Kamboj SK, Swanson GT, Cull-Candy SG (1995) Intracellular spermine confers rectification on rat calcium-permeable AMPA and kainate receptors. J Physiol 486:297-303.

Kauer JA, Malenka RC (2007) Synaptic plasticity and addiction. Nat Rev Neurosci 8:844-858.

Khan ZU, Gutiérrez A, Martín R, Peñafiel A, Rivera A, de la Calle A (2000) Dopamine $\mathrm{D}_{5}$ receptors of rat and human brain. Neuroscience 100:689-699.

Kim SJ, Linden DJ (2007) Ubiquitous plasticity and memory storage. Neuron 56:582-592.

Kopec CD, Real E, Kessels HW, Malinow R (2007) GluR1 links structural and functional plasticity at excitatory synapses. J Neurosci 27:13706-13718.

Lacey MG, Mercuri NB, North RA (1990) Actions of cocaine on rat dopaminergic neurones in vitro. Br J Pharmacol 99:731-735.

Liu SQ, Cull-Candy SG (2000) Synaptic activity at calcium-permeable AMPA receptors induces a switch in receptor subtype. Nature 405:454-458.

Liu QS, Pu L, Poo MM (2005) Repeated cocaine exposure in vivo facilitates LTP induction in midbrain dopamine neurons. Nature 437:1027-1031.

Lu XY, Churchill L, Kalivas PW (1997) Expression of D1 receptor mRNA in projections from the forebrain to the ventral tegmental area. Synapse 25:205-214.

Malenka RC, Bear MF (2004) LTP and LTD: an embarrassment of riches. Neuron 44:5-21.

Malinow R, Malenka RC (2002) AMPA receptor trafficking and synaptic plasticity. Annu Rev Neurosci 25:103-126.

Mameli M, Balland B, Luján R, Lüscher C (2007) Rapid synthesis and synaptic insertion of GluR2 for mGluR-LTD in the ventral tegmental area. Science 317:530-533.

Mangiavacchi S, Wolf ME (2004) Stimulation of N-methyl-D-aspartate receptors, AMPA receptors or metabotropic glutamate receptors leads to rapid internalization of AMPA receptors in cultured nucleus accumbens neurons. Eur J Neurosci 20:649-657.

Margolis EB, Lock H, Hjelmstad GO, Fields HL (2006) The ventral tegmental area revisited: is there an electrophysiological marker for dopaminergic neurons? J Physiol 577:907-924.

Navakkode S, Sajikumar S, Frey JU (2007) Synergistic requirements for the induction of dopaminergic D1/D5-receptor-mediated LTP in hippocampal slices of rat CA1 in vitro. Neuropharmacology 52:1547-1554.

Nestler EJ (2005) Is there a common molecular pathway for addiction? Nat Neurosci 8:1445-1449.

Nilsen A, England PM (2007) A subtype-selective, use-dependent inhibitor of native AMPA receptors. J Am Chem Soc 129:4902-4903.

Pan WJ, Hedaya MA (1998) An animal model for simultaneous pharmacokinetic/pharmacodynamic investigations: application to cocaine. J Pharmacol Toxicol Methods 39:1-8.

Pierce RC, Born B, Adams M, Kalivas PW (1996) Repeated intra-ventral tegmental area administration of SKF-38393 induces behavioral and neurochemical sensitization to a subsequent cocaine challenge. J Pharmacol Exp Ther 278:384-392.

Plant K, Pelkey KA, Bortolotto ZA, Morita D, Terashima A, McBain CJ, Collingridge GL, Isaac JT (2006) Transient incorporation of native GluR2-lacking AMPA receptors during hippocampal long-term potentiation. Nat Neurosci 9:602-604.

Ritz MC, Lamb RJ, Goldberg SR, Kuhar MJ (1987) Cocaine receptors on dopamine transporters are related to self-administration of cocaine. Science 237:1219-1223.

Saal D, Dong Y, Bonci A, Malenka RC (2003) Drugs of abuse and stress trigger a common synaptic adaptation in dopamine neurons. Neuron 37:577-582.

Sarti F, Borgland SL, Kharazia VN, Bonci A (2007) Acute cocaine exposure alters spine density and long-term potentiation in the ventral tegmental area. Eur J Neurosci 26:749-756.

Schilström B, Yaka R, Argilli E, Suvarna N, Schumann J, Chen BT, Carman M, Singh V, Mailliard WS, Ron D, Bonci A (2006) Cocaine enhances NMDA receptor-mediated currents in ventral tegmental area cells via dopamine $\mathrm{D}_{5}$ receptor-dependent redistribution of NMDA receptors. J Neurosci 26:8549-8558.

Seiden LS, Sabol KE, Ricaurte GA (1993) Amphetamine: effects on catecholamine systems and behavior. Annu Rev Pharmacol Toxicol 33:639-677. 
Shi SH, Hayashi Y, Petralia RS, Zaman SH, Wenthold RJ, Svoboda K, Malinow R (1999) Rapid spine delivery and redistribution of AMPA receptors after synaptic NMDA receptor activation. Science 284:1811-1816.

Smith WB, Starck SR, Roberts RW, Schuman EM (2005) Dopaminergic stimulation of local protein synthesis enhances surface expression of GluR1 and synaptic transmission in hippocampal neurons. Neuron 45:765-779.

Song I, Huganir RL (2002) Regulation of AMPA receptors during synaptic plasticity. Trends Neurosci 25:578-588.

Stanton PK, Sarvey JM (1984) Blockade of long-term potentiation in rat hippocampal CA1 region by inhibitors of protein synthesis. J Neurosci 4:3080-3088.

Steward O, Schuman EM (2001) Protein synthesis at synaptic sites on dendrites. Annu Rev Neurosci 24:299-325.
Sutton MA, Schuman EM (2006) Dendritic protein synthesis, synaptic plasticity, and memory. Cell 127:49-58.

Turecek R, Vlcek K, Petrovic M, Horak M, Vlachova V, Vyklicky L Jr (2004) Intracellular spermine decreases open probability of $N$-methyl-Daspartate receptor channels. Neuroscience 125:879-887.

Ungless MA, Whistler JL, Malenka RC, Bonci A (2001) Single cocaine exposure in vivo induces long-term potentiation in dopamine neurons. Nature 411:583-587.

Vezina $\mathrm{P}$ (1996) $\mathrm{D}_{1}$ dopamine receptor activation is necessary for the induction of sensitization by amphetamine in the ventral tegmental area. J Neurosci 16:2411-2420.

Yung KK, Bolam JP, Smith AD, Hersch SM, Ciliax BJ, Levey AI (1995) Immunocytochemical localization of D1 and D2 dopamine receptors in the basal ganglia of the rat: light and electron microscopy. Neuroscience 65: $709-730$. 